\title{
Land-use and agriculture in Denmark around year 1900 and the quest for EU Water Framework Directive reference conditions in coastal waters
}

\author{
Bent T. Christensen, Birger F. Pedersen, Jørgen E. Olesen, \\ Jørgen Eriksen (1)
}

Received: 28 September 2020/Revised: 28 January 2021 / Accepted: 4 February 2021/Published online: 18 March 2021

\begin{abstract}
The EU Water Framework Directive (WFD) aims to protect the ecological status of coastal waters. To establish acceptable boundaries between good and moderate ecological status, the WFD calls for reference conditions practically undisturbed by human impact. For Denmark, the nitrogen $(\mathrm{N})$ concentrations present around year 1900 have been suggested to represent reference conditions. As the $\mathrm{N}$ load of coastal waters relates closely to runoff from land, any reduction in load links to agricultural activity. We challenge the current use of historical $\mathrm{N}$ balances to establish WFD reference conditions and initiate an alternative approach based on parish-level land-use statistics collected 1896/1900 and N concentrations in root zone percolates from experiments with year 1900-relevant management. This approach may be more widely applicable for landscapes with detailed historic information on agricultural activity. Using this approach, we find an average $\mathrm{N}$ concentration in root zone percolates that is close to that of current agriculture. Thus, considering Danish coastal waters to be practically unaffected by human activity around year 1900 remains futile as $75 \%$ of the land area was subject to agricultural activity with a substantial potential for $\mathrm{N}$ loss to the environment. It appears unlikely that the ecological state of coastal waters around year 1900 may serve as WFD reference condition.
\end{abstract}

Keywords Abuse of $\mathrm{N}$ balances - Agricultural management $\cdot$ Coastal water eutrophication $\cdot$ EU water framework directive . Historic parish-level land-use

\section{INTRODUCTION}

The EU Water Framework Directive (WFD 2000) represents a crucial step in regulating the ecological quality of coastal waters (the water body stretching $1.85 \mathrm{~km}$ from the coastline). It aims to protect the biological quality and to reestablish good ecological status for surface waters adversely affected by human activity. Since no universal quality standard applies to all coastal waters, the WFD calls for a defined status of a given water body that corresponds to no or only very minor anthropogenic impacts compared to that of undisturbed conditions, termed reference conditions. The reference condition is a key element in establishing the important boundary between good and moderate status of a given coastal area and in any regulation of anthropogenic inputs (e.g. Skarbøvik et al. 2020). The guidance document associated with the WDF (WDFCIS-5 2003) outlines a hierarchical approach for deriving reference conditions in coastal waters: existing undisturbed sites, historical information, models, and expert judgements. However, attempts to define reference conditions most often combine these approaches.

The ecological status around year 1900 has repeatedly been promoted as defining reference conditions in Danish coastal waters (Baattrup-Pedersen et al. 2008; Andersen et al. 2011; Kaas et al. 2015; Jensen 2017). It is assumed that the anthropogenic impact at that time was negligible as judged from historic distributions of eelgrass (Zostera marina L.) and concentrations of chlorophyll a derived from water transparency measured by Secchi depth. However, the variability of eelgrass abundance within a 
given coastal area (e.g. Krause-Jensen et al. 2005; Kuusemäe et al. 2016) may compromise eelgrass as universal ecological indicator (Riemann et al. 2016). The observed links between Secchi depth, chlorophyll a, and nitrogen (N) concentrations prompted $\mathrm{N}$ levels in coastal waters as an indicator for ecological status (Nielsen et al. 2002; Henriksen 2009; Schernewski et al. 2015) even though no universal relationship exists between chlorophyll a and $\mathrm{N}$ concentrations (Carstensen et al. 2011).

Defining targets for $\mathrm{N}$ use in agriculture is of relevance to all EU member states and has attracted much attention in the Baltic area (e.g. Gustafsson et al. 2012; Wulff et al. 2014; Andersen et al. 2017; Skarbøvik et al. 2020). Indeed, it has very high priority in Denmark as $62 \%$ of the land area is currently subject to agricultural activity and the $\mathrm{N}$ load to coastal waters relates closely to runoff from land. Small watercourses, distributed across the land and draining to coastal areas with different ecological susceptibility, may lead to widely different regional reduction targets in $\mathrm{N}$ use. However, measurements of $\mathrm{N}$ concentrations in Danish streams around year 1900 are extremely few (Westermann 1898) and their representativeness uncertain. The $\mathrm{N}$ load of coastal waters in year 1900 therefore remains currently unknown.

Several European studies combine expert judgements and historical data with hindcast modelling to establish WFD reference conditions 100 to 150 years ago (Gustafsson et al. 2012; Hirt et al. 2014; Schernewski et al. 2015; Andersen et al. 2017), assuming insignificant anthropogenic $\mathrm{N}$ loads or involving historical $\mathrm{N}$ balances with the $\mathrm{N}$ surplus linked to $\mathrm{N}$ leaching from land. This may lead to substantial negative $\mathrm{N}$ balances (Hirt et al. 2014) with subsequent upscaling of negative to positive surplus to comply with model requirements (Gadegast et al. 2012). Negative $\mathrm{N}$ surplus certainly questions the feasibility of historic $\mathrm{N}$ balances in estimating $\mathrm{N}$ loss potential from agricultural land.

The nutrient status of Danish coastal water around year 1900 relies on current $\mathrm{N}$ contents in streams with negligible human impact and national $\mathrm{N}$ surplus for agriculture year 1900 (Kaas et al. 2015; Jensen 2017). Based on pristine catchments and estimates of national $\mathrm{N}$ surplus, this approach is open for criticisms as agricultural activity around 1900 affected $75 \%$ of the land area (Danmarks Statistik 1968).

Here we apply a critical perspective on the use of $\mathrm{N}$ balances to predict historic $\mathrm{N}$ loading of coastal waters for establishing $\mathrm{N}$ reduction needs to comply with WFD objectives. Further, we initiate an alternative approach that focuses on the source strength (i.e. $\mathrm{N}$ concentration in water leaving the root zone) using parish-level statistics on land-use (collected 1896/1900) and nitrate-N in percolates from field experiments with year 1900-relevant management. This allows for future calculations of $\mathrm{N}$ in water reaching Danish coasts in 1900 and for testing the relevance of using year 1900 as hallmark for WFD reference conditions.

\section{HISTORICAL ASPECTS OF DANISH AGRICULTURE}

The statistics on land-use and agriculture in this section relate to land under Danish administration before 1920 . During 1861-1896, the area in agricultural use increased dramatically and accounted for $75 \%$ in 1896 . The area in rotational cropping increased by 546000 ha (Jensen 1988), and heathlands and sand dunes declined by 656000 ha during 1850-1907 (Mortensen 1969). Bare fallow with vegetation-free soil subject to frequent tillage throughout a year was widespread (Christensen 1898). First introduced in Denmark in the 1850s, tile-drainage affected $26 \%$ of the agricultural area by year 1907 with 300000 ha being drained during 1871-1881 (Jensen 1988).

\section{Crop production and $\mathrm{N}$ use}

Crop production around 1900 differed markedly from that of current agriculture: crops with low yield potentials, inferior horse-drawn implements, high weed pressure, lack of chemical plant protection, and inefficient plant nutrient supply. Mineral $\mathrm{N}$ fertilizer use averaged $1 \mathrm{~kg} \mathrm{~N} \mathrm{ha}^{-1}$ (Danmarks Statistik 1968), the main sources of $\mathrm{N}$ being animal manure and $\mathrm{N}_{2}$-fixing crops. The annual average (1900-1904) application of $\mathrm{N}$ in manure was $21 \mathrm{~kg} \mathrm{~N} \mathrm{ha}^{-1}$ when corrected for $15 \%$ loss of $\mathrm{N}$ during feeding and $25 \%$ loss of N during manure storage (Danmarks Statistik 1968) but not accounting for loss of $\mathrm{N}$ after field application.

In 1896, storage tanks for liquid manure accounted to 28 000 (Iversen 1944) while manure heaps with roof covers were 16500 in 1907. There was 237000 farms and smallholdings with farmland and another 35000 holdings without land (Christensen 1985). Thus, only a small proportion of the holdings had proper manure storages, facilitating substantial volatilization and leaching losses of manure-N. Field application of manure occurred typically during late summer, autumn and early winter, due to cultivation of autumn-sown crops, lack of manure storage capacity, and the availability of farm labour. Manures applied during this period provide a poor $\mathrm{N}$-use-efficiency and substantial leaching potentials of mineral $\mathrm{N}$ present in the manure or mineralized from organically bound $\mathrm{N}$ outside the active growing season.

The grain yields for oats, barley, rye and wheat around 1900 averaged $1.4,1.8,2.0$ and $2.8 \mathrm{t} \mathrm{ha}^{-1}$, respectively (Danmarks Statistik 1968). These yields align with those 
achieved during 1894-1904 in the Askov long-term field experiments, in plots kept unmanured for more than 120 years (Christensen et al. 2019), and in unmanured plots in ongoing organic farming experiments (Olesen et al. 2002; Shah et al. 2017). Hay production on rotational and permanent grassland (incl. meadows) yielded 2.4 and $2.7 \mathrm{t}$ $\mathrm{ha}^{-1}$, respectively (Danmarks Statistik 1968). Even though contemporary textbooks prescribed generous use of liquid manure to meadows, permanent grasslands and grass-clover crops in rotation in late autumn and again in the spring (Christensen 1898), yield levels were below those obtained currently for rotational grass-clover grown under unmanured conditions (Christensen et al. 2019).

The typical crop rotation in 1900 was spring cereals (mainly oats) undersown with grass-clover, 3 to 5 years in grass-clover followed by 1 year in bare fallow, and finally autumn-sown cereals (mainly winter rye), and/or a root crop (Christensen 1898). Fertile soils supported more crops of spring-sown oats before soil nutrients were exhausted and a new grass-clover crop was established.

\section{Animal production}

Animal husbandry also differed from current Danish agriculture for most production factors: livestock composition, feed quality and rate of feeding, grazing intensity and periods, and productivity per animal unit. Converted into livestock units $(1$ cow $=1$ livestock unit; LU), the agricultural sector included 2.6 million LU in 1898 (Danmarks Statistik 1969) with $54 \%$ cattle, $16 \%$ pigs, $15 \%$ horses, $8 \%$ poultry, and 7\% sheep and goats. Grass ingested in fresh condition dominated ruminant forage $(49 \%)$, while root crops, hay and cereal straw accounted for $19 \%, 18 \%$, and 13\%, respectively (Danmarks Statistik 1968). Grazing accounted for more than $70 \%$ of the feed intake (Kristensen et al. 2015).

\section{Farm structure}

The farm structure differed fundamentally from that of current Danish agriculture with most of the agricultural production currently concentrated on 10000 farms. At that time, most farms were small in terms of acreage and production volume. Farm sizes were measured in hartkorn (Hkt), a unit that combines land area, land-use and soil quality providing an estimate of the production potential of individual farms. Smallholdings $(<1 \mathrm{Hkt})$ and smaller farms ( 1 to $8 \mathrm{Hkt}$ ) accounted in 1895 for $74 \%$ of the total agricultural production (Christensen 1985). Cattle herds encompassing 1 to 14 cows accounted for $70 \%$ of all cows and the average animal density in 1898 was $0.89 \mathrm{LU} \mathrm{ha}^{-1}$ on land under agricultural use (Danmarks Statistik 1969).

\section{THE USE AND ABUSE OF NITROGEN BALANCES}

The use of historical $\mathrm{N}$ balances to establish WFD reference conditions implies an intimate link between $\mathrm{N}$ application and $\mathrm{N}$ leaching. Howarth et al. (1996) found a linear relationship between net anthropogenic $\mathrm{N}$ inputs (NANI; atmospheric deposition + fertilizer $\mathrm{N}$ application + agricultural $\mathrm{N}_{2}$ fixation $+\mathrm{N}$ in net food and feed imports) and $\mathrm{N}$ loss to coastal waters, the regional $\mathrm{N}$ fluxes in rivers averaging $25 \%$ of the calculated NANI. In that study, mineral $\mathrm{N}$ fertilizer dominated NANI. Hong et al. (2012) and Wulff et al. (2014) adopted the NANI concept to predict current riverine $\mathrm{N}$ export and estimate reduction targets at national scales. They concluded that NANI related closely to riverine nutrient fluxes and that meeting water quality targets may require substantial changes in the agricultural sector. However, Howarth et al. (2012) stated that the NANI approach, originally developed for very large regions, was likely to break down when applied to smaller watersheds. The NANI concept neglects changes in $\mathrm{N}$ residing in soil organic matter pools and that farm structure and field management affect crop N-use-efficiency. The latter is of particular importance when comparing agriculture with substantial differences in technology level.

Calculations of $\mathrm{N}$ surplus used in hindcast models considers agricultural activity within a given catchment as one big farm (Fig. 1), thereby neglecting important internal $\mathrm{N}$ flows within the catchment and the volatilization of ammonia from animal housings and manure storage. Further, it ignores the use-efficiency of $\mathrm{N}$ inputs from animal manures and $\mathrm{N}_{2}$ fixation. A farm-gate balance does not account for the impact of management on the distribution of the field surplus $\mathrm{N}$ between leaching, ammonia volatilization, denitrification, and changes in the soil $\mathrm{N}$ pool (Fig. 2). However, setting up a historical field balance requires detailed information on inputs and outputs of $\mathrm{N}$, and on $\mathrm{N}$ turnover rates at field level, information that is rarely available.

For current agriculture, the field $\mathrm{N}$ surplus and associated $\mathrm{N}$ leaching losses from the root zone shows little or no correlation (Blicher-Mathiesen et al. 2014, 2019; Eriksen et al. 2015; Hansen et al. 2015). Analysing 39 streams from catchments with between 0 and $90 \%$ of the area in agricultural use, Kronvang et al. (2015) found a good correlation between percentage of land in agriculture and the flow-weighted $\mathrm{N}$ concentration in streams without including the field N surplus. Chambers et al. (2012) reported similar results in a Canadian study. For Danish shallow lakes, Nielsen et al. (2012) showed a good relation between $\mathrm{N}$ concentration and percentage of land in agriculture while field $\mathrm{N}$ surplus showed no correlation. The lack of correlation between field $\mathrm{N}$ surplus and $\mathrm{N}$ leaching may reflect 


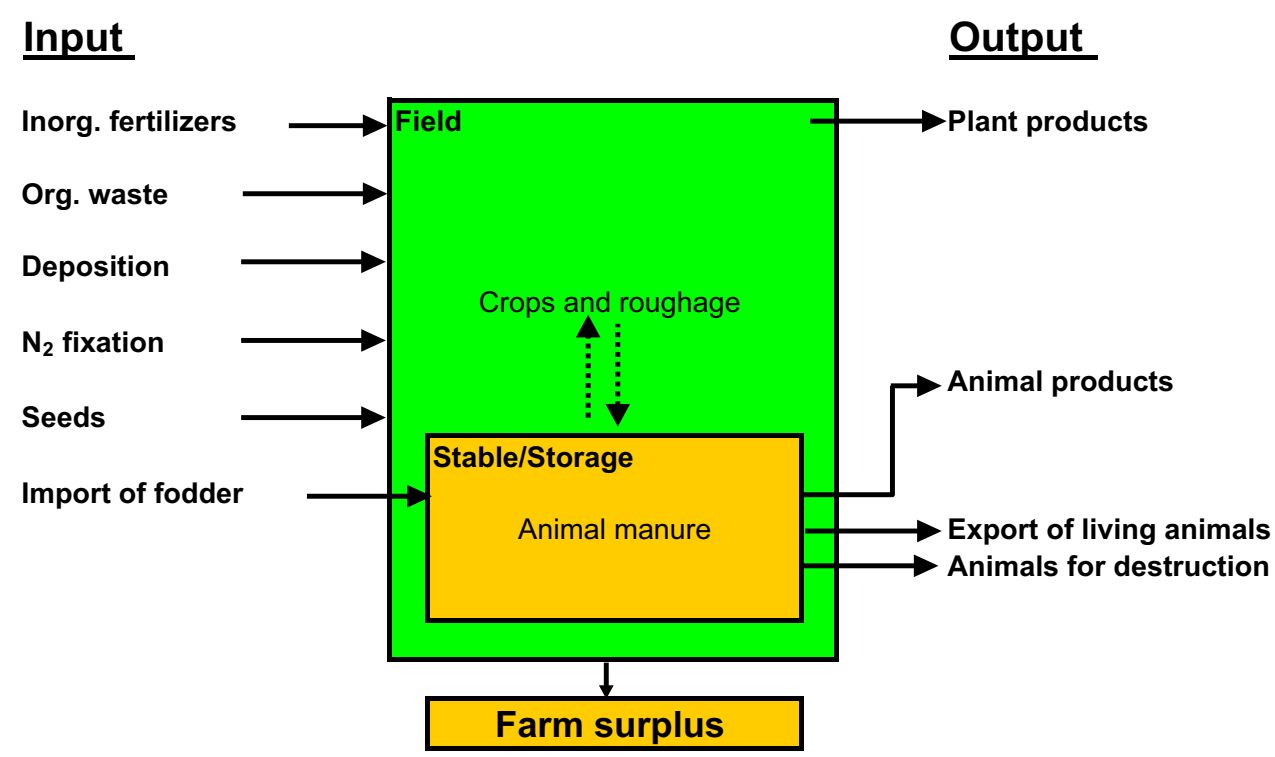

Fig. 1 Farm-gate $\mathrm{N}$ balance approach

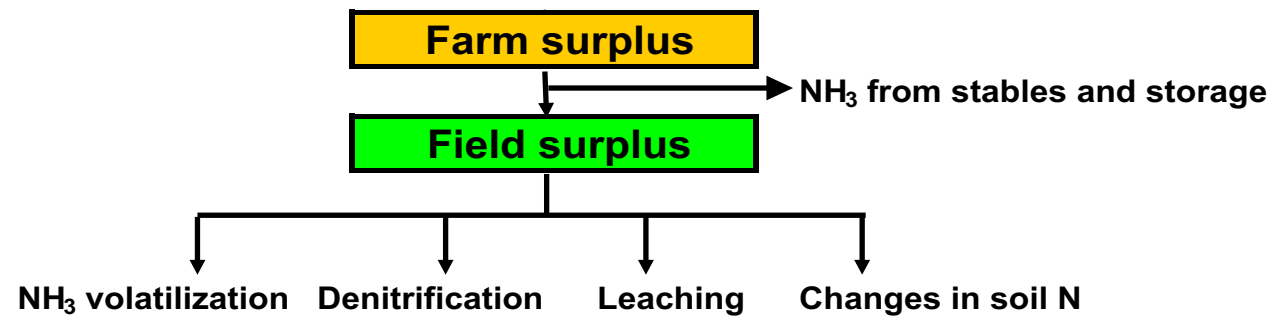

Fig. 2 Distribution of farm-gate $\mathrm{N}$ surplus on ammonia volatilization from stables and manure storage, and the distribution of the resulting field $\mathrm{N}$ surplus

changes in the soil $\mathrm{N}$ pool and the dominating importance of field management.

Around year 1900, the N leaching most likely constituted a high proportion of the $\mathrm{N}$ surplus. Large areas of land had been included in rotational cropping in the preceding decades and there was a widespread use of bare fallow. Moreover, much of the arable land had recently been tile-drained and autumn application of manure enhanced N leaching losses. Drainage of waterlogged soil increases aeration and thereby the turnover of soil organic matter, promoting mineralization of $\mathrm{N}$ from the soil pool. Conversion of permanently vegetated land into arable rotation initiates a decrease in soil organic matter content that lingers on for decades. Whitmore et al. (1992) found that ploughing of permanent grassland reduced the soil $\mathrm{N}$ pool by up to $40 \%$ over a period of 20 years. Howden et al. (2010) found similar effects of cultivation. There is little doubt that in year 1900 significant losses in soil organic $\mathrm{N}$ occurred on areas that had been brought into cultivation and drained in the previous decades. Although the growing crops recovered part of the mineralized soil $\mathrm{N}$, nitrate leaching most likely accounted for a substantial part of the decline as $\mathrm{N}$ mineralisation continued outside the growing season. There was a widespread use of spring-sown crops with manure applications in the autumn and leaving the ploughed soil bare during the autumn and winter periods. Neglecting the cultivation-induced loss of soil $\mathrm{N}$ may lead to negative $\mathrm{N}$ surplus as observed in previous studies (Gadegast et al. 2012; Hirt et al. 2014).

\section{PARISH-LEVEL STATISTICS (1896/1900)}

Andersson and Arheimer (2003) applied a parish-level approach to establish historical $\mathrm{N}$ discharge from a catchment in South Central Sweden, including three land-use categories, historical information on land management, and model simulations of $\mathrm{N}$ leaching. Here we establish year 1900 estimates of nitrate- $\mathrm{N}$ in root zone percolates for eight land-use categories derived from historic parish-level 
Table 1 Land-use data collected in 1896 in parishes under Danish administration (3 880000 ha; Statens Statistiske Bureau \& Danmarks Statistik 1898)

\begin{tabular}{|c|c|c|}
\hline Code & Land-use category & $\%$ of total area \\
\hline DA1 & Wheat & 0.9 \\
\hline DA2 & Cereal rye & 7.6 \\
\hline DA3 & Barley & 7.4 \\
\hline DA4 & Oats & 11.6 \\
\hline DA5 & Mixed cereals (mature) & 3.1 \\
\hline DA6 & Buckwheat & 0.3 \\
\hline DA7 & Pulses & 0.2 \\
\hline DA8 & Spurrey (mature) & 0.2 \\
\hline DA9 & Caraway and oil-seed rape & $<0.0$ \\
\hline DA10 & Seed production (clover, grass, beets, lupines) & 0.1 \\
\hline DA11 & Potatoes & 1.4 \\
\hline DA12 & Sugar beets and chicory & 0.3 \\
\hline DA13 & Carrots & 0.2 \\
\hline DA14 & Fodder beets & 1.8 \\
\hline DA15 & $\begin{array}{l}\text { Green forage (mixed cereals, spurrey, } \\
\text { lucerne) }\end{array}$ & 1.3 \\
\hline DA16 & Flax, hemp and tobacco & $<0.0$ \\
\hline DA17 & Garden crops & $<0.0$ \\
\hline DA18 & Black fallow (vegetation-free) & 5.1 \\
\hline DA19 & $\begin{array}{l}\text { Black fallow (green manure before } \\
\text { ploughing) }\end{array}$ & 0.1 \\
\hline DA20 & Semi-black fallow (early summer-crop) & 1.4 \\
\hline DA21 & Cultivated grass for hay & 6.9 \\
\hline DA22 & Cultivated grass for grazing & 17.9 \\
\hline DA23 & Meadows & 6.0 \\
\hline DA24 & Fens and commons & 2.5 \\
\hline DA25 & Moors and peatland & 2.0 \\
\hline DA26 & Hedgerows and shelters & 0.2 \\
\hline DA27 & Gardens and plant nurseries & 0.9 \\
\hline DA28 & Forest area (planted) & 6.3 \\
\hline DA29 & Forest area (unplanted) & 0.7 \\
\hline DA30 & Heathland & 9.2 \\
\hline DA31 & Sand dunes and shifting sands & 1.1 \\
\hline DA32 & Swamp, foreshores, stone fields etc. & 0.4 \\
\hline DA33 & Roads, building sites and storage areas & 2.3 \\
\hline DA34 & Lakes, ponds, streams (outside sea territory) & 0.3 \\
\hline Total & & 100 \\
\hline
\end{tabular}

statistics and $\mathrm{N}$ concentrations in percolates measured in well-defined field experiments with year 1900-relevant management.

From 1864 to 1920, the southern part of Jutland (Northern part of Schleswig) was under German administration. However, we obtained parish statistics for areas under Danish and German administration in 1896 and 1900, respectively, and thereby covers the current Danish territory. The parish boundaries have remained almost unchanged since year 1900 and thus the parish represents probably the most conservative land area unit. Each parish collected detailed information on land-use every 5 to 10 years. The present study relies on 1766 parish units.

The Danish administration allocated the total area of each parish into 34 land-use categories (here coded DA, Table 1), while the German administration applied 51 categories (here coded TY, Table 2). We merged the two sets of data into 26 categories using the Danish categories as template (coded S, Table 3 ). Figure 3 shows the relative distribution of selected land-uses at the parish level. Next, we condensed the $26 \mathrm{~S}$-coded land-use categories into eight DK-categories (Table 4) to align major land-uses with current year 1900-relevant $\mathrm{N}$ concentrations in root zone percolates.

\section{ESTIMATES OF N CONCENTRATIONS IN ROOT ZONE PERCOLATES}

Results from field experiments with year 1900-relevant management allowed us to link specific and well-known management with $\mathrm{N}$ concentrations in root zone percolates from agricultural soils. For forest-covered areas, we relied on $\mathrm{N}$ concentration in soil solutions retrieved from the bottom of the root zone.

The $\mathrm{N}_{2}$ fixation depends on crop species and competition with companion non-fixing plants. Average annual yields of grass-clover leys grown during 1907-1922 in animal-manured plots of the Askov long-term field experiments was $4.8 \mathrm{t} \mathrm{DM} \mathrm{ha}^{-1}$ (Iversen and Dorph-Petersen 1951) of which $42 \%$ was clover biomass. Using an empirical model (Høgh-Jensen et al. 2004) for grass-clover leys, $\mathrm{N}_{2}$ fixation ranged 117 to $183 \mathrm{~kg} \mathrm{~N} \mathrm{ha}^{-1}$. However, the fate of this $\mathrm{N}$ remains difficult to quantify.

Mineralization of organically bound $\mathrm{N}$ outside the growing season represents a substantial potential for $\mathrm{N}$ leaching. Following unfertilized grassland, terminated in the spring and then seeded to spring barley, Eriksen et al. (2008) found an annual flow-weighted nitrate concentration of $36 \mathrm{mg} \mathrm{N} \mathrm{L}^{-1}$ in drainage following the barley crop. Leaching of $\mathrm{N}$ can be substantial from grasslands subject to long grazing periods. Around year 1900, grasslands received liquid manure in the early spring and after having delivered a first cut of hay, grazing continued until late autumn (Christensen 1898) with urination by grazing animals creating locally very high inputs of mobile N. For a 4-year old grass-clover field, subject to grazing from late April to late October, Hansen et al. (2012) estimated that urination affected one-third of the area, giving rise to $23 \mathrm{mg} \mathrm{N} \mathrm{L}^{-1}$ in the root zone percolate. When exposed to a grass cut in the spring and then subjected to grazing, the $\mathrm{N}$ concentration was $19 \mathrm{mg} \mathrm{N} \mathrm{L}^{-1}$. 
Table 2 Land-use data collected in 1900 in parishes under German administration (390 000 ha; Engelbrecht 1907)

\begin{tabular}{|c|c|c|}
\hline $\begin{array}{l}\text { Category } \\
\text { code }\end{array}$ & Land-use category & $\%$ of total area \\
\hline TY1 & Winter wheat & 1.6 \\
\hline TY2 & Spring wheat & $<0.0$ \\
\hline TY3 & Winter rye & 5.6 \\
\hline TY4 & Spring rye & $<0.0$ \\
\hline TY5 & Winter barley & $<0.0$ \\
\hline TY6 & Spring barley & 4.4 \\
\hline TY7 & Oats & 8.9 \\
\hline TY8 & Mixed cereals (winter) & $<0.0$ \\
\hline TY9 & Mixed cereals (summer) & 2.1 \\
\hline TY10 & Buckwheat & 0.7 \\
\hline TY11 & Peas & 0.1 \\
\hline TY12 & Fava bean & $<0.0$ \\
\hline TY13 & Vetch & $<0.0$ \\
\hline TY14 & Mixed cereals & 0.4 \\
\hline TY15 & Mixed pulses & $<0.0$ \\
\hline TY16 & Other types & $<0.0$ \\
\hline TY17 & Potatoes & 1.0 \\
\hline TY18 & Sugar beets & $<0.0$ \\
\hline TY19 & Fodder beets & 0.6 \\
\hline TY20 & Carrots & 0.1 \\
\hline TY21 & Fodder radish & 0.1 \\
\hline TY22 & Swedes & 1.3 \\
\hline TY23 & Field herbs and caddish & $<0.0$ \\
\hline TY24 & Other types & $<0.0$ \\
\hline TY25 & Winter rape and radish & $<0.0$ \\
\hline TY26 & Leindotter (Camelina sativa) & $<0.0$ \\
\hline TY27 & Flax & $<0.0$ \\
\hline TY28 & Other types & $<0.0$ \\
\hline TY29 & Clover (for forage) & 1.0 \\
\hline TY30 & Lucerne & $<0.0$ \\
\hline TY31 & Serradella & $<0.0$ \\
\hline TY32 & Spurrey & $<0.0$ \\
\hline TY33 & $\begin{array}{l}\text { Seed production (clover, grass- } \\
\text { clover) }\end{array}$ & 4.2 \\
\hline TY34 & Maize & $<0.0$ \\
\hline TY35 & Vetch & $<0.0$ \\
\hline TY36 & Lupines (for forage) & $<0.0$ \\
\hline TY37 & Mixed legumes & 0.2 \\
\hline TY38 & Mixed vegetables (for forage) & $<0.0$ \\
\hline TY39 & Mustard & $<0.0$ \\
\hline TY40 & Lupines & $<0.0$ \\
\hline TY41 & Mixed vegetables & $<0.0$ \\
\hline TY42 & Mustard & $<0.0$ \\
\hline TY43 & Fallow & 3.3 \\
\hline TY44 & Cultivated grass & 25.0 \\
\hline TY45 & Gardens and fruit plantations & 0.7 \\
\hline TYG & Meadows & 10.7 \\
\hline
\end{tabular}

Table 2 continued

\begin{tabular}{llc}
\hline $\begin{array}{l}\text { Category } \\
\text { code }\end{array}$ & Land-use category & $\%$ of total area \\
\hline TYH & Pastures & 11.1 \\
TYI & Forests & 3.6 \\
TYJ & Buildings and yards & 0.7 \\
TYK & Uncultivated land & 5.8 \\
TYL & Roads and lakes, ponds, streams & 6.7 \\
Total & & 100 \\
\hline
\end{tabular}

A study of organic crop rotations was initiated in 1997 at three Danish sites varying in climate and soil type (Olesen et al. 2000). The rotation was grass-clover ley, winter cereals, spring cereals, and either a potato or a grain legume crop. Animal manure was applied at an average annual rate of $70 \mathrm{~kg} \mathrm{~N} \mathrm{ha}^{-1}\left(\sim 0.7 \mathrm{LU} \mathrm{ha}^{-1}\right)$ and nitrate leaching measured at the bottom of the root zone (Askegaard et al. 2011). The flow-weighted nitrate concentration in percolates averaged $12 \mathrm{mg} \mathrm{N} \mathrm{L}^{-1}$ and was remarkable constant across sites and three rotation cycles. However, amounts of $\mathrm{N}$ lost by leaching differed between sites as percolation ranged 238 to $637 \mathrm{~mm}$. Eriksen et al. (1999) provide results from an organic rotation addressing cattle production. Nutrients added in liquid and bedding-rich farmyard manure and from grazing cattle corresponded to $0.9 \mathrm{LU} \mathrm{ha}{ }^{-1}$. The rotation was spring barley undersown with grass-clover, two years with grass-clover, barley/pea, winter wheat and beetroots. The grass-clover was cut once early in the growth period and then exposed to grazing. Except for lack of bare fallow, the rotation and its management, including nutrient load, corresponded well with a year 1900 scenario. The average flow-weighed nitrate concentration in water leaving the root zone was $13 \mathrm{mg} \mathrm{N}$ $\mathrm{L}^{-1}$ for spring-sown crops (barley undersown with grassclover and barley/pea mixture), $18 \mathrm{mg} \mathrm{N} \mathrm{L}^{-1}$ for winter wheat, $9 \mathrm{mg} \mathrm{N} \mathrm{L}^{-1}$ for grass-clover (first and second year grass-clover), and $12 \mathrm{mg} \mathrm{N} \mathrm{L}^{-1}$ for the root crop. These values are associated with DK-codes 1 to 4 in Table 4 .

Soils under bare fallow show significant $\mathrm{N}$ leaching losses. For unmanured bare fallow, Thomsen et al. (1993) found an annual average $\mathrm{N}$ leaching over a four-year period of $104 \mathrm{~kg} \mathrm{~N} / \mathrm{ha}$, nitrate in the leachate being $21 \mathrm{mg} \mathrm{N} \mathrm{L}^{-1}$. Experiments with permanent fallow, established in 1870 at Rothamsted Experimental Station, showed a nitrate-N concentration of $19 \mathrm{mg} \mathrm{N} \mathrm{L}^{-1}$ when averaged over seven years of fallow (Addiscott, 1988). For fallow (DK-5), the nitrate-N concentration was set to $20 \mathrm{mg} \mathrm{N} \mathrm{L}^{-1}$ (Table 4).

We apply a concentration of $1 \mathrm{mg} \mathrm{N} \mathrm{L}^{-1}$ for non-forest areas under natural vegetation (DK-6). We assume that in areas without net-gain in standing vegetation biomass and soil $\mathrm{N}$ storage, the leaching of $\mathrm{N}$ reflects deposition of $\mathrm{N}$, 
Table 3 DA and TY land-use categories and distribution merged into 26 S-categories

\begin{tabular}{|c|c|c|c|c|c|}
\hline Code & Land-use category & Area (ha) & $\%$ of total area & DA code & TY code \\
\hline S01 & Wheat & 41428 & 1.0 & 1 & 1,5 \\
\hline $\mathrm{S} 02$ & Cereal rye & 315998 & 7.3 & 2 & 3 \\
\hline S03 & Barley & 301057 & 7.0 & 3 & 6 \\
\hline S04 & Oats & 479084 & 11.1 & 4 & 7 \\
\hline S05 & Mixed cereals & 129831 & 3.0 & 5 & $2,4,8,9$ \\
\hline S06 & Buckwheat & 14530 & 0.3 & 6 & 10 \\
\hline S07 & Pulses & 11600 & 0.3 & 7 & $11,12,13,14,15,16$ \\
\hline S08 & Spurrey & 7641 & 0.2 & 8 & 32 \\
\hline S09 & Caraway and rape & 525 & $<0.0$ & 9 & $25,39,42$ \\
\hline $\mathrm{S} 10$ & Seed production & 25028 & 0.6 & 10 & $29,30,31,33$ \\
\hline S11 & Potatoes & 56743 & 1.3 & 11 & 17 \\
\hline $\mathrm{S} 12$ & Sugar beets & 13583 & 0.3 & 12 & 18 \\
\hline $\mathrm{S} 13$ & Carrots & 6535 & 0.2 & 13 & 20 \\
\hline $\mathrm{S} 14$ & Fodder beets & 76910 & 1.8 & 14 & $19,21,22$ \\
\hline $\mathrm{S} 15$ & Green forage & 51277 & 1.2 & 15 & $23,24,35,36,37,38,40$ \\
\hline $\mathrm{S} 16$ & Flax, hemp and tobacco & 293 & $<0.0$ & 16 & 27,28 \\
\hline $\mathrm{S} 17$ & Garden crops & 37549 & 0.9 & 17,27 & 45 \\
\hline $\mathrm{S} 18$ & Fallow & 267843 & 6.2 & $18,19,20$ & 43 \\
\hline S19 & Cultivated grass & 1053714 & 24.5 & 21,22 & 44 \\
\hline $\mathrm{S} 20$ & Meadows, fens and commons & 407621 & 9.5 & 23,24 & $\mathrm{G}, \mathrm{H}$ \\
\hline $\mathrm{S} 21$ & Moors, peat- and heathland & 587555 & 13.7 & $25,30,31,32$ & $\mathrm{~K}$ \\
\hline $\mathrm{S} 22$ & Forest & 295580 & 6.9 & $26,28,29$ & I \\
\hline $\mathrm{S} 23$ & Roads and building sites & 88336 & 2.1 & 33 & No code \\
\hline $\mathrm{S} 24$ & Lakes, ponds and streams & 13086 & 0.3 & 34 & No code \\
\hline $\mathrm{S} 25$ & Buildings and yards & 2967 & 0.1 & No code & $\mathrm{J}$ \\
\hline $\mathrm{S} 26$ & Roads and water areas & 17441 & 0.4 & No code & $\mathrm{L}$ \\
\hline Total & & 4303762 & 100 & & \\
\hline
\end{tabular}

and that $\mathrm{N}_{2}$ fixation and denitrification balance out. The first systematic measurements of $\mathrm{N}$ in rainwater, made in the period 1921-1926 at four research stations across the country, showed an annual deposition of $\mathrm{N}$ in ammonium and nitrate ranging 6 to $11 \mathrm{~kg} \mathrm{~N}^{-1}$ (Hansen 1931).

For $\mathrm{N}$ lost from forest (DK-7), we rely on studies of forests with different size and age (Callesen et al. 1999; Hansen et al. 2007). The average concentration of $\mathrm{N}$ in soil solutions extracted from 75 to $100 \mathrm{~cm}$ soil depth in forests with an area of $<10$ ha, 10-50 ha and $>50$ ha was 3.0, 2.0 and $1.3 \mathrm{mg} \mathrm{N} \mathrm{L}^{-1}$, respectively. For a coniferous stand $<45$ years grown on a nutrient poor location, the $\mathrm{N}$ concentration in $90 \mathrm{~cm}$ soil depth ranged 0.5 to $1 \mathrm{mg} \mathrm{N}$ $\mathrm{L}^{-1}$. Percolates from deciduous forests on a more nutrient rich locality varied around $4 \mathrm{mg} \mathrm{N} \mathrm{L}^{-1}$, generally with the smallest values under younger stands. Concentrations of $\mathrm{N}$ increased with increasing stand age on more nutrient rich soils. The value for forest was set to $2 \mathrm{mg} \mathrm{N} \mathrm{L}^{-1}$ (Table 4).
For other land-use (DK-8), we do not estimate a concentration as this land-use code categorizes as point sources or recipients.

\section{REFLECTIONS AND RESERVATIONS ON ROOT ZONE ESTIMATES}

The $\mathrm{N}$ concentrations for the land-use categories autumnand spring-sown crops, grass-clover and root crops are from well-monitored field experiments under organic farming with an animal stocking density of $0.9 \mathrm{LU} \mathrm{ha}^{-1}$. Although organic cropping excludes mineral fertilizers and chemical crop protection, current crop varieties with animal manure applied in the spring are superior compared to those used in year 1900 with most of the manure applied in periods with large potentials for $\mathrm{N}$ leaching. The increased $\mathrm{N}$-use-efficiency associated with modern crops grown on 
Oats
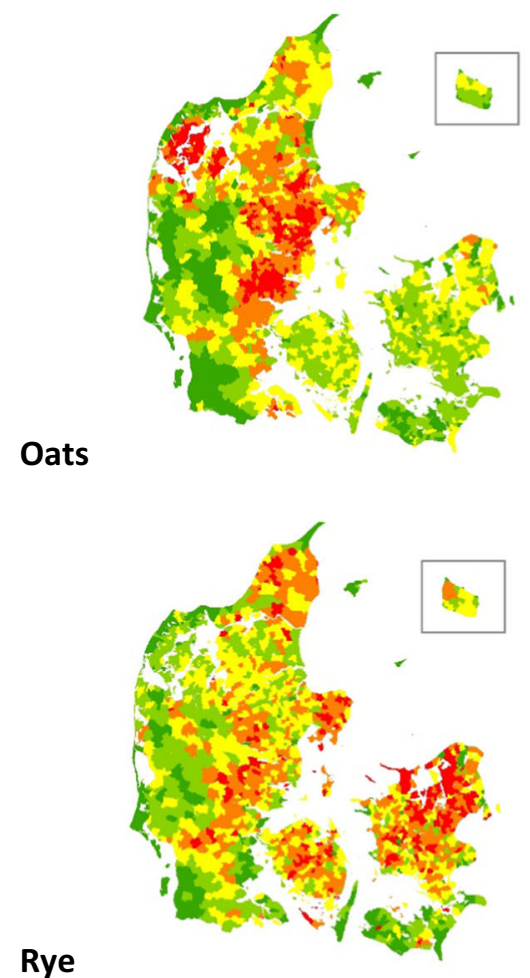

Wheat

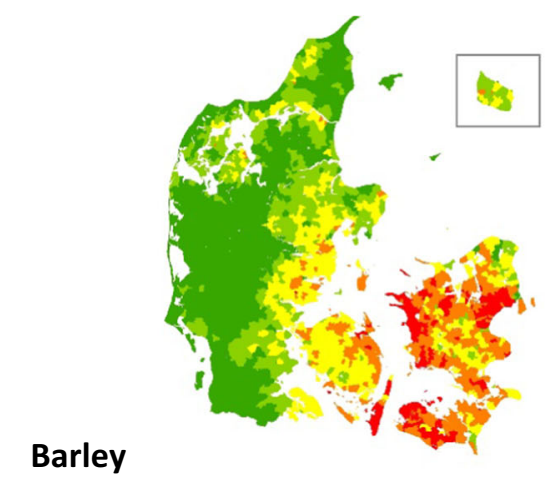

Barley

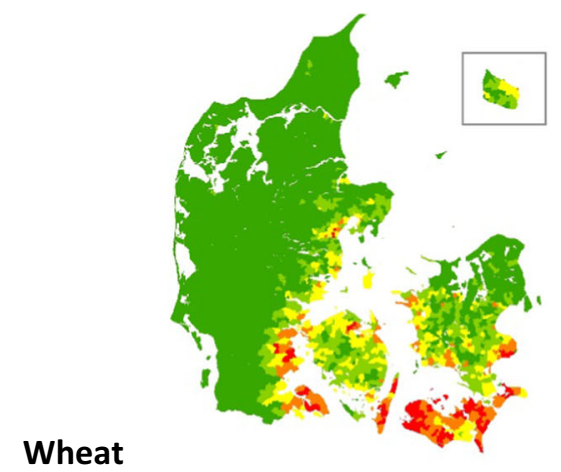

Fallow

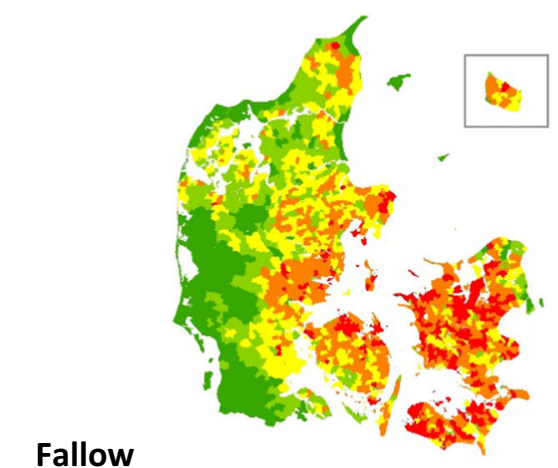

Grass

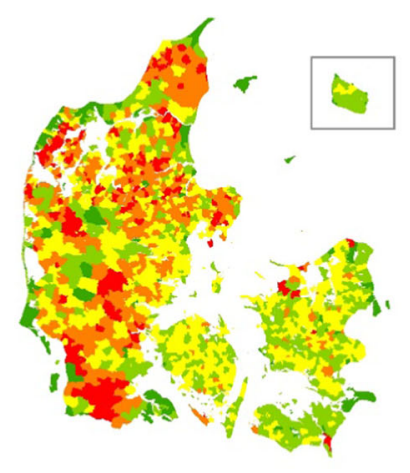

\section{Nature}

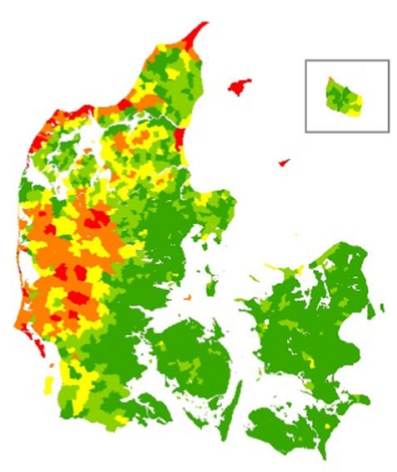

Forest

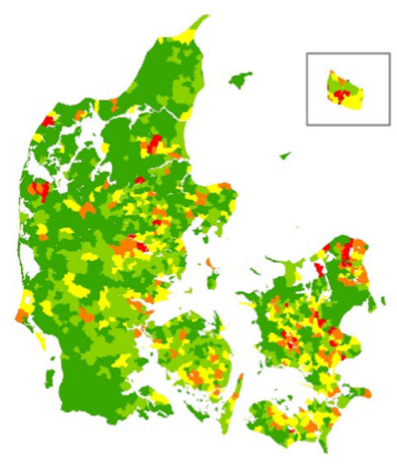

Fig. 3 Relative abundance of oats, barley, cereal rye, wheat, grassland, fallow, nature (uncultivated land) and forest at parish level in 1896/1900

well-drained soils and spring application of manure leads to higher yields than obtained year 1900 . The higher N-useefficiency in current organic field experiments may underestimate $\mathrm{N}$ leaching in year 1900 agriculture. However, an inferior quality of manure associated with year 1900 animal husbandry may balance this discrepancy. 
Table 4 DK-model codes merged from S codes: Land-use, areas and nitrate-N concentrations in roots zone percolates for each DK-model category. Area adjusted to the total area of Parish maps 1900

\begin{tabular}{|c|c|c|c|c|c|}
\hline \multirow[t]{2}{*}{ DK code } & \multicolumn{3}{|l|}{ Land-use and area } & \multirow[b]{2}{*}{$\mathrm{S}$ land-use codes } & \multirow{2}{*}{$\begin{array}{l}\text { Nitrate- } \mathrm{N} \text { concentration } \\
\mathrm{mg} \mathrm{N} \mathrm{L}\end{array}$} \\
\hline & Land-use category & 1000 ha & $\%$ & & \\
\hline DK-1 & Winter crops & 357 & 8.3 & 1,2 & 18 \\
\hline DK-2 & Spring crops & 982 & 22.8 & $3,4,5,6,7,8,9,16,17$ & 13 \\
\hline DK-3 & Grass & 1538 & 35.7 & $10,15,19,20$ & 9 \\
\hline DK-4 & Roots & 154 & 3.6 & $11,12,13,14$ & 12 \\
\hline DK-5 & Fallow & 268 & 6.2 & 18 & 20 \\
\hline DK-6 & Nature & 588 & 13.7 & 21 & 1 \\
\hline DK-7 & Forest & 296 & 6.9 & 22 & 2 \\
\hline DK-8 & Other land-use & 122 & 2.8 & $23,24,25,26$ & 0 \\
\hline Total & & 4305 & 100 & & \\
\hline
\end{tabular}

Moreover, cultivation of native land and tile draining during 1860 to 1900 introduced a large and long-lasting decrease in soil $\mathrm{N}$ storage, adding an annual background leaching loss of 10 to $100 \mathrm{~kg} \mathrm{~N} \mathrm{ha}^{-1}$ to that associated with management practised year 1900 .

Based on historic land-use and measurements in current year 1900-relevant crop rotations, the mean annual nitrate concentration in root zone percolates from Danish agriculture becomes $12 \mathrm{mg} \mathrm{N} \mathrm{L}^{-1}$. This is comparable to concentrations of $14 \mathrm{mg} \mathrm{N} \mathrm{L}^{-1}$ determined in the Danish Agricultural Catchment Monitoring Program (LOOP) during 2004-2016 (Blicher-Mathiesen et al. 2019) but lower than the $28 \mathrm{mg} \mathrm{N} \mathrm{L}^{-1}$ found for 1990-1994. For the south and central Sweden, similar results were found for agricultural soils when comparing nitrate leaching in the late part of the 19th century to that in the 1980s (Hoffmann et al. 2000; Andersson and Arheimer 2003).

Our study excludes leaching losses of ammonium and organically bound $\mathrm{N}$. The concentration of ammonium in drainage water collected during 1971-1991 from five loamy soils in agricultural use averaged $0.12 \mathrm{mg} \mathrm{N} \mathrm{L}^{-1}$ (Simmelsgaard 1996). Studies on root zone percolates from two sandy soils under grass-clover crops showed average ammonium and organic $\mathrm{N}$ concentrations of 0.05 and $1.4 \mathrm{mg} \mathrm{N} \mathrm{L}^{-1}$, respectively (Vinther et al. 2006). Thus, we consider that the concentrations of these forms of $\mathrm{N}$ remain inferior compared to those of nitrate- $\mathrm{N}$.

\section{PERSPECTIVES}

Using Denmark as a case study, we find that the use of parish-level land-use statistics and field experiments with year 1900-relevant management initiates a valid alternative approach to establish the export of $\mathrm{N}$ from land to coastal waters. Combined with hydrological models on catchment scales and using year 1900 precipitation patterns and retention of $\mathrm{N}$ in landscape elements, this may provide realistic estimates of the historic $\mathrm{N}$ load to individual coastal waters. We venture that this approach may be more widely applicable for catchments with detailed historic information on agricultural activity. However, in accordance with previous studies (Clarke et al. 2003; Henriksen 2009; Topcu et al. 2011; Duarte et al. 2015; Skarbøvik et al. 2020), we question the relevance of reference conditions based on historic catchment-scale $\mathrm{N}$ balances, crude categories of land-use, and hindcast modelling.

Denmark has since 1985 implemented a number of actions plans to reduce ammonia volatilization and nitrate leaching from agricultural activities (Dalgaard et al. 2014). Since 1990, this reduced the N input from diffuse land sources to coastal waters by $43 \%$ and resulted in significant declines in concentrations of $\mathrm{N}$ and chlorophyll a (Riemann et al. 2016). However, a non-linear response of $\mathrm{N}$ reduction to improvement in water quality may be expected (Duarte et al. 2009, 2015; Riemann et al. 2016) due to release of nutrients accumulated in landscape elements and sediments, change in catchment hydrology, and other environmental changes whether natural or induced by human activities.

The WFD (2000), adopted as national legislation in Denmark in 2003, requires reference conditions that represent no or very minor impacts from human activity to be established for coastal waters. We submit that considering year 1900 as a period where Danish coastal waters were almost unaffected by human activity remains unsupported as $75 \%$ of the land area was subject to agricultural activity with a substantial potential for $\mathrm{N}$ leaching losses to the aquatic environment. We conclude that the ecological state of coastal areas around year 1900 is unlikely to serve as WFD reference conditions.

Duarte et al. $(2009,2015)$ challenged central elements in the WFD, including the concept that a sufficient reduction 
of $\mathrm{N}$ use on agricultural land automatically return the ecological state of coastal waters to that existing in some idealized pre-perturbation period. Duarte et al. (2009) stated that this expectation is as likely as the existence of Neverland. We agree that return to Neverland cannot be an ambition but remains an illusion.

Acknowledgements We gratefully acknowledge the technical assistance of Eva Overby Bach.

Open Access This article is licensed under a Creative Commons Attribution 4.0 International License, which permits use, sharing, adaptation, distribution and reproduction in any medium or format, as long as you give appropriate credit to the original author(s) and the source, provide a link to the Creative Commons licence, and indicate if changes were made. The images or other third party material in this article are included in the article's Creative Commons licence, unless indicated otherwise in a credit line to the material. If material is not included in the article's Creative Commons licence and your intended use is not permitted by statutory regulation or exceeds the permitted use, you will need to obtain permission directly from the copyright holder. To view a copy of this licence, visit http://creativecommons. org/licenses/by/4.0/

\section{REFERENCES}

Addiscott, T.M. 1988. Long-term leakage of nitrate from bare unmanured soil. Soil Use and Management 4: 91-95.

Andersen, J.H., P. Axe, H. Backer, J. Carstensen, U. Claussen, V. Fleming-Lehtinen, M. Järvinen, H. Kaartokallio, et al. 2011. Getting the measure of eutrophication in the Baltic Sea: Towards improved assessment principles and methods. Biogeochemistry 106: $137-156$.

Andersen, J.H., J. Carstensen, D.J. Conley, K. Dromph, V. FlemingLehtinen, B.G. Gustafsson, A.B. Josefson, A. Norkko, et al. 2017. Long-term temporal and spatial trends in eutrophication status of the Baltic Sea. Biological Reviews 92: 135-149.

Andersson, L., and B. Arheimer. 2003. Modelling of human and climatic impact on nitrogen load in a Swedish river 1885-1994. Hydrobiologia 497: 63-77.

Askegaard, M., J.E. Olesen, I.A. Rasmussen, and K. Kristensen. 2011. Nitrate leaching from organic arable crop rotations is mostly determined by autumn field management. Agriculture, Ecosystems \& Environment 142: 149-160.

Baattrup-Pedersen, A., G. Springe, T. Riis, S.E. Larsen, K. SandJensen, and L.M.K. Larsen. 2008. The search for reference conditions for stream vegetation in Northern Europe. Freshwater Biology 53: 1890-1901.

Blicher-Mathiesen, G., H.E. Andersen, and S.E. Larsen. 2014. Nitrogen field balances and suction cup-measured $\mathrm{N}$ leaching in Danish catchments. Agriculture, Ecosystems \& Environment 196: 69-75.

Blicher-Mathiesen G., H. Holm, T. Houlborg, J. Rolighed, H.E. Andersen, M.V. Carstensen, P.G. Jensen, J. Wienke, et al. 2019. Danish Agricultural Cachment Monitoring Program 2017. Scientific Report from DCE-Danish Centre for Environment and Energy, Report No. 305 (in Danish).

Callesen, I., K. Raulund-Rasmussen, P. Gundersen, and H. Stryhn. 1999. Nitrate concentrations in soil solutions below Danish forests. Forest Ecology and Management 114: 71-82.

Carstensen, J., M. Sánchez-Camacho, C.M. Duarte, D. Krause-Jensen, and N. Marbà. 2011. Connecting the dots: Responses ecosystems to changing nutrient concentrations. Environmental Science and Technology 45: 9122-9132.

Chambers, P.A., D.J. McGoldrick, R.B. Brua, C. Vis, J.M. Culp, and G.A. Benoy. 2012. Development of environmental thresholds for nitrogen and phosphorus in streams. Journal of Environmental Quality 41: 7-20.

Christensen, C. 1898. Agricultural crop plants (Landbrugets kulturplanter). Copenhagen: August Bangs Boghandels Forlag (in Danish).

Christensen, J. 1985. Agricultural Statistics. Handbook in Danish Agricultural Statistics (Landbostatistik. Håndbog i dansk landbohistorisk statistik) 1830-1900. Copenhagen: Landbohistorisk Selskab (in Danish).

Christensen, B.T, I.K. Thomsen, and J. Eriksen. 2019. The Askov Long-Term Experiments: 1894-2019-A Unique Research Platform Turns 125 Years. DCA Report No. 151, March 2019, DCA-Danish Centre for Food and Agriculture, Aarhus University.

Clarke, A., S. Juggins, and D. Conley. 2003. A 150-year reconstruction of the history of coastal eutrophication in Roskilde Fjord, Denmark. Marine Pollution Bulletin 46: 1615-1618.

Dalgaard, T., B. Hansen, B. Hasler, O. Hertel, N.J. Hutchings, B.H. Jacobsen, L.S. Jensen, B. Kronvang, et al. 2014. Policies for agricultural nitrogen management - trends, challenges and prospects for improved efficiency in Denmark. Environmental Research Letters 9: Paper 115002.

Danmarks Statistik. 1968. Agricultural Statistics 1900-1965, Volume I: Agricultural area and harvest and utilization of fertilizers. Copenhagen: Danmarks Statistik (in Danish, English summary).

Danmarks Statistik. 1969. Agricultural statistics 1900-1965, Volume II: Livestock and livestock products and consumption of feeding stuffs. Copenhagen: Danmarks Statistik (in Danish, English summary).

Duarte, C.M., A. Borja, J. Carstensen, M. Elliott, D. Krause-Jensen, and N. Marbà. 2015. Paradigms in the recovery of estuarine and coastal ecosystems. Estuaries and Coasts 38: 1202-1212.

Duarte, C.M., D.J. Conley, J. Carstensen, and M. Sánchez-Camacho. 2009. Return to Neverland: Shifting baselines affect eutrophication restoration targets. Estuaries and Coasts 32: 29-36.

Engelbrecht, T.H. 1907. Bodenanbau und Viehstand in SchleswigHolstein nach Ergebnissen der amtlichen Statistik. II, Anhang, Tabelle 1 (in German).

Eriksen, J., M. Askegaard, and K. Kristensen. 1999. Nitrate leaching in an organic dairy/crop rotation as affected by organic manure type, livestock density and crop. Soil Use and Management 15: 176-182.

Eriksen, J., M. Askegaard, J. Rasmussen, and K. Søegaard. 2015. Nitrate leaching and residual effect in dairy crop rotations with grass-clover leys as influenced by sward age, grazing, cutting and fertilizer regimes. Agriculture, Ecosystems \& Environment 212: 75-84.

Eriksen, J., M. Askegaard, and K. Søegaard. 2008. Residual effect and nitrate leaching in grass-arable rotations: Effect of grassland proportion, sward type and fertilizer history. Soil Use and Management 24: 373-382.

Gadegast, M., U. Hirt, D. Opitz, and M. Venohr. 2012. Modelling changes in nitrogen emissions into the Oder River System 1875-1944. Regional Environmental Change 12: 571-580.

Gustafsson, B.G., F. Schenk, T. Blenckner, K. Eilola, H.E.M. Meier, B. Müller-Karulis, T. Neumann, T. Ruoho-Airola, et al. 2012. Reconstructing the development of Baltic Sea eutrophication 1850-2006. Ambio 41: 534-548. https://doi.org/10.1007/s13280012-0318-x.

Hansen, F. 1931. Studies on rainwater (Undersøgelser af regnvand). Tidsskrift for Planteavl 37: 123-150 (in Danish). 
Hansen, E.M., J. Eriksen, K. Søegaard, and K. Kristensen. 2012. Effects of grazing strategy on limiting nitrate leaching in grazed grass-clover pastures on coarse sandy soil. Soil Use and Management 28: 478-487.

Hansen, E.M., L.J. Munkholm, J.E. Olesen, and B. Melander. 2015. Nitrate leaching, yields and carbon sequestration after noninversion tillage, catch crops, and straw retention. Journal of Environmental Quality 44: 868-881.

Hansen, K., L. Rosenqvist, L. Vesterdal, and P. Gundersen. 2007. Nitrate leaching from three afforestation chronosequences on former arable land in Denmark. Global Change Biology 13: $1250-1264$.

Henriksen, P. 2009. Reference conditions for phytoplankton at Danish Water Framework Directive intercalibration sites. Hydrobiologia 629: 255-262.

Hirt, U., J. Mahnkopf, M. Gadegast, L. Czudowski, U. Mischke, C. Heidecke, G. Schernewski, and M. Venohr. 2014. Reference conditions for rivers of the German Baltic Sea catchment: Reconstructing nutrient regimes using the model MONERIS. Regional Environmental Change 14: 1123-1138.

Hoffmann, M., H. Johnsson, A. Gustafson, and A. Grimvall. 2000. Leaching of nitrogen in Swedish Agriculture-A historical perspective. Agriculture, Ecosystems \& Environment 80: 277-290.

Høgh-Jensen, H., R. Loges, F.V. Jørgensen, F.P. Vinther, and E.S. Jensen. 2004. An empirical model for quantification of symbiotic nitrogen fixation in grass-clover mixtures. Agricultural Systems 82: 181-194.

Hong, B., D.P. Swaney, C.-M. Mörth, E. Smedberg, H.E. Hägg, C. Humborg, R.W. Howarth, and F. Bouraoui. 2012. Evaluating regional variation of net anthropogenic nitrogen and phosphorus inputs (NANI/NAPI), major drivers, nutrient retention pattern and management implications in the multinational areas of Baltic Sea basin. Ecological Modelling 227: 117-135.

Howarth, R.W., G. Billen, D. Swaney, A. Townsend, N. Jaworski, K. Lajtha, J.A. Downing, R. Elmgren, et al. 1996. Regional nitrogen budgets and riverine $\mathrm{N} \& \mathrm{P}$ fluxes for the drainages to the North Atlantic Ocean: Natural and human influence. Biogeochemistry 35: 75-139.

Howarth, R., D. Swaney, G. Billen, J. Garnier, B. Hong, C. Humborg, P. Johnes, C.-M. Mörth, et al. 2012. Nitrogen fluxes from the landscape are controlled by net anthropogenic nitrogen inputs and by climate. Frontiers in Ecology and the Environment 10: $37-43$.

Howden, N.J.K., T.P. Burt, F. Worral, M.J. Whelam, and M. Bieroza. 2010. Nitrate concentrations and fluxes in the River Thames over 140 years (1868-2008): Are increases irreversible? Hydrological Processes 24: 2657-2662.

Iversen, K. 1944. Farmyard manure and liquid manure (Staldgødning og ajle). In Den Ny Landmandsbog, Bind I, Planteavl, ed. K.A. Bondorff and J. Petersen-Dalum Westermann, 281-320. Copenhagen: Egmont H. Petersen, Kgl. Hof-Bogtrykkeri (in Danish).

Iversen, K., and K. Dorph-Petersen. 1951. Experiments with farmyard manure and mineral fertilizers at Askov (Forsøg med staldgødning og kunstgødning ved Askov) 1894-1948. Tidsskrift for Planteavl 54: 369-538 (in Danish).

Jensen, S.P. 1988. Statistical overview (Statistisk oversigt). In Det danske landbrugs historie III - 1810-1914, ed. C. Bjørn, 250-265. Copenhagen: Landbohistorisk Selskab (in Danish).

Jensen, P.N. (ed). 2017. Estimation of nitrogen concentrations from root zone to marine areas around the year 1900. Aarhus University, DCE-Danish Centre for Environment and Energy, Scientific Report from DCE No. 241.

Kaas, H., K. Timmermann, A.C. Erichsen, J.P.A. Christensen, C. Murray, and S. Markager. 2015. Establishing chlorophyll a limits in fjords and coastal areas using model tools (Fastlæggelse af klorofyl a grænseværdier i fjorde og kystområder ved brug af modelværktøjer). DCE-Nationalt Center for Miljø og Energi, Report 7. May 2015 (in Danish).

Krause- Jensen, D., T.M. Greve, and K. Nielsen. 2005. Eelgrass as a bioindicators under the European Water Framework Directive. Water Resources Management 19: 63-75.

Kristensen, T., O. Aaes, and M.R. Weisbjerg. 2015. Production and environmental impact of dairy cattle production in Denmark 1900-2010. Livestock Science 178: 306-312.

Kronvang, B., J. Windolf, S.E. Larsen, and J. Bøgestrand. 2015. Background concentrations and loadings of nitrogen in Danish surface waters. Acta Agriculturae Scandinavica B65: 155-163.

Kuusemäe, K., E.K. Rasmussen, P. Canal-Vergés, and M.R. Flindt. 2016. Modelling stressors on the eelgrass recovery process in two Danish estuaries. Ecological Modelling 333: 11-42.

Mortensen, E. 1969. They lead the way (De viste vejen). Copenhagen: Landhusholdningsselskabets Forlag (in Danish).

Nielsen, S.L., K. Sand-Jensen, J. Borum, and O. Geertz-Hansen. 2002. Phytoplankton, nutrients, and transparency in Danish coastal waters. Estuaries 25: 930-937.

Nielsen, A., D. Trolle, M. Søndergaard, T.L. Lauridsen, R. Bjerring, J.E. Olesen, and E. Jeppesen. 2012. Watershed land use effects on lake water quality in Denmark. Ecological Applications 22: $1187-1200$.

Olesen, J.E., M. Askegaard, and I.A. Rasmussen. 2000. Design of an organic farming crop rotation experiment. Acta Agriculturae Scandinavica B50: 13-21.

Olesen, J.E., I.A. Rasmussen, M. Askegaard, and K. Kristensen. 2002. Whole-rotation dry matter and nitrogen grain yields from the first course of an organic farming crop rotation experiment. Journal of Agricultural Science, Cambridge 139: 361-370.

Riemann, B., J. Carstensen, K. Dahl, H. Fossing, J.W. Hansen, H.H. Jakobsen, A.B. Josefson, D. Krause-Jensen, et al. 2016. Recovery of Danish coastal ecosystems after reductions in nutrient loading: A holistic ecosystem approach. Estuaries and Coasts 39: 82-97.

Schernewski, G., R. Friedland, M. Carstens, U. Hirt, W. Leujak, G. Nausch, T. Neumann, T. Petenati, et al. 2015. Implementation of European marine policy: New water quality targets for German Baltic waters. Marine Policy 51: 305-321.

Shah, A., M. Askegaard, I.A. Rasmussen, E.M.C. Jimenez, and J.E. Olesen. 2017. Productivity of organic and conventional arable cropping systems in Denmark. European Journal of Agronomy 90: $12-22$.

Simmelsgaard, S.E. 1996. Plant nutrients in subsurface drainage water and soil water. SP Report 7, Statens Planteavlsfors $\varnothing$, Tjele (in Danish, English summary).

Skarbøvik, E., J. Aroviita, J. Fölster, A.L. Solheim, K. Kyllmar, K. Rankinen, and B. Kronvang. 2020. Comparing nutrient reference concentrations in Nordic countries with focus on lowland rivers. Ambio 49: 1771-1783. https://doi.org/10.1007/s13280-02001370-4.

Statens Statistiske Bureau \& Danmarks Statistik. 1898. Land-use Statistics in Denmark (Arealets Benyttelse i Danmark) den 15. juli 1896 (Statistisk Tabelværk Rk. 5 Litra C Nr 1). Bianco Lunos Hof-Trykkeri (F. Dreyer), Copenhagen (in Danish).

Thomsen, I.K., J.F. Hansen, V. Kjellerup, and B.T. Christensen. 1993. Effects of cropping system and rates of nitrogen in animal slurry and mineral fertilizer on nitrate leaching from a sandy loam. Soil Use and Management 9: 53-58.

Topcu, D., H. Behrendt, U. Brockmann, and U. Claussen. 2011. Natural background concentrations of nutrients in the German Bight area (North Sea). Environmental Monitoring and Assessment 174: 361-388. 
Vinther, F.P., E.M. Hansen, and J. Eriksen. 2006. Leaching of soil organic carbon and nitrogen in sandy soils after cultivating grass-clover swards. Biology and Fertility of Soils 43: 12-19.

Westermann, T. 1898. On the content of plant nutrients in major streams (Om indholdet af plantenæring i vandet fra vore vandløb). Tidsskrift for Landbrugets Planteavl 4: 157-165 (in Danish).

WFD. 2000. Directive 2000/60/EC of the European Parliament and of the Council of 23. October 2000 establishing a framework for Community action in the field of water policy. Official Journal of the European Communities L 327/1: 1-72.

WFD-CIS-5. 2003. Common implementation strategy for the Water Framework Directive (2000/60/EC)—Guidance Document No. 5. Transitional and Coastal Waters. Office for Official Publications of the European Communities, Luxembourg.

Whitmore, A.P., N.J. Bradbury, and P.A. Johnson. 1992. Potential contribution of ploughed grassland to nitrate leaching. Agriculture, Ecosystems \& Environment 39: 221-233.

Wulff, F., C. Humborg, H.E. Andersen, G. Blicher-Mathiesen, M. Czajkowski, K. Elofsson, A. Fonnesbech-Wulff, B. Hasler, et al. 2014. Reduction of Baltic Sea nutrient inputs and allocation of abatement costs within the Baltic Sea catchment. Ambio 43: 11-25. https://doi.org/10.1007/s13280-013-0484-5.

Publisher's Note Springer Nature remains neutral with regard to jurisdictional claims in published maps and institutional affiliations.

\section{AUTHOR BIOGRAPHIES}

Bent T. Christensen is Professor in Soil Fertility at the Department of Agroecology at Aarhus University, AU-Foulum. His research includes carbon and nitrogen turnover in soil and the interaction between crop production and the environment.
Address: Department of Agroecology, Aarhus University, AU-Foulum, Blichers Allé 20, P.O. Box 50, 8830 Tjele, Denmark. e-mail: bent.t.christensen@agro.au.dk

Birger F. Pedersen is Academic employee at Department of Agroecology, Aarhus University. He is database manager of the national FRJOR database, which includes data for area based subsidy, manure and fertilizer use (GR) and holdings and animals from Central Husbandry Register (CHR). The database is involved in researchbased policy support.

Address: Department of Agroecology, Aarhus University, AU-Foulum, Blichers Allé 20, P.O. Box 50, 8830 Tjele, Denmark. e-mail: birgerf.pedersen@agro.au.dk

Jørgen E. Olesen is Professor in Climate Change and Agriculture and Head of Department at Department of Agroecology, Aarhus University. His research covers carbon and nitrogen cycling in agroecosystems and its linkages to environmental conditions.

Address: Department of Agroecology, Aarhus University, AU-Foulum, Blichers Allé 20, P.O. Box 50, 8830 Tjele, Denmark.

e-mail: jeo@agro.au.dk

Jørgen Eriksen $(\bowtie)$ is Professor in Nutrient Cycling in Agroecosystems at the Department of Agroecology, Aarhus University. His research includes nutrient cycling, nutrient use efficiency and losses in conventional and organic farming systems.

Address: Department of Agroecology, Aarhus University, AU-Foulum, Blichers Allé 20, P.O. Box 50, 8830 Tjele, Denmark.

e-mail: jorgen.eriksen@agro.au.dk 